\title{
INTERNATIONAL Legal COOPERATION AND Procedural IsSues: Lessons FROM ADMINISTRATIVE AND ENVIRONMENTAL LAW
}

\author{
Ricardo Perlingeiro ${ }^{1}$ \\ Estácio de Sá University, Brazil
}

\begin{abstract}
The present project endeavors to identify, discuss and consolidate the procedural principles of international legal cooperation in the law of States called upon to cooperate with another. The research methodology includes the analysis of the current procedural rules of international legal cooperation under the laws of Brazil, the United Kingdom and the European Union, with a focus on administrative and environmental law.
\end{abstract}

Contents: 1 Introduction. 2 Authorities of the Requested State that are competent to rule on the request for cooperation. 3 Standing to initiate the international cooperation process. 4 Translation and interpretation in the process of international legal cooperation. 5 Content of the decision resulting from the review of compatibility with the Requested State's public policy. 6 Efficacy of the public policy review decision. 7 Timing of the public policy review process.

Keywords: International Legal Cooperation, public policy, mutual assistance, administrative law, environmental law.

\section{INTRODUCTION}

The international legal cooperation discussed in this article is associated with coordinated action among States with the objective of ensuring that the basic state functions, such as enforcement and protection of rights (conflict resolution) are effective across borders whenever necessary.

On the one hand, from the standpoint of the international human rights system, States have the duty to safeguard negative and positive freedoms, which includes both protecting individual rights and punishing those who violate the rights of others. If the nature of such public duties requires them to cross national borders, the State that is requested to cooperate has a duty and not just a discretionary power to enable international legal cooperation.

On the other hand, from the standpoint of national law, the Requested States must protect their sovereign power to investigate and control public order, i.e., the Requested States must cooperate internationally to the extent that such cooperation is compatible with its

\footnotetext{
${ }^{1}$ Professor at Estácio de Sá University/ MA and PhD Programs in Law (Rio de Janeiro).
} 
fundamental principles and with its own version of the concept of due process of law, both substantive and procedural.

International legal cooperation therefore depends on rules of procedure influenced by the position of the Requested States, which are caught between international duties to cooperate, on the one hand, and constitutional duties to refrain from cooperating in order to preserve their own ordre publique [public policy].

In this context, the present study endeavors to identify, discuss and consolidate the procedural principles of the review of compatibility of a cooperative act with public policy (hereinafter referred to as "public policy review" for short) to be exercised by the authorities and courts of one State that is called upon to cooperate with another. The research methodology includes an analysis of the procedural rules of international legal cooperation in effect under the laws of Brazil, the United Kingdom and the European Union with a focus on administrative and environmental law.

\section{Authorities Of THE ReQuested State that ARE COMPETENT to RULE ON THE REQUEST FOR COOPERATION}

What is the sphere of the decision-making power in the Requested State that is competent to weigh the interests between the international duty to cooperate and the national duty to protect public policy?

The answer depends on the provisions of the Requested State's current laws concerning the characteristics of the act of cooperation to be practiced in its territory and which of its bodies are constitutionally competent to perform such acts.

For example, imagine it is necessary to enforce a ruling of a foreign environmental authority intended to prohibit an industry located in the territory of the Requested State and near the bank of a river that drains into the territory of the Requesting State. If, in the Requested State, administrative authorities are competent to enforce environmental administrative decisions, then those same authorities would be responsible for the process of reviewing the ruling to ensure compatibility with national public policy; if only the courts could enforce administrative decisions, as is frequently the case in Brazil, then the courts would be responsible for reviewing the compatibility of the foreign administrative decision with the public policy of the Requested State. 


\section{STANDING TO INITIATE THE INTERNATIONAL COOPERATION PROCESS}

Who is competent to initiate the review process in international legal cooperation? Apropos, is it a review that must be initiated by the interested parties or is it initiated ex officio by the authorities of the Requested State?

In the case of a measure of international legal cooperation intended to exercise a right beyond the national borders, exclusively the rights-holder can take the initiative. Thus, any person who feels harmed by the implementation of an act of cooperation is required to take the initiative to ask the competent authority for review of the international legal cooperation. This is true not only of civil law issues, which would make it very obvious, but also issues of administrative law with respect to the defense of an individual against administrative decisions that deprive citizens of rights. In the case of vulnerable persons, however, such as minors, it is understandable that they are always represented by specific authorities in the Requested States.

If the international cooperation involves a request to another country's state prosecution authorities to take action on their own territory, as in the case of transborder enforcement of the powers of an environmental authority, the review process must be initiated by the judicial and administrative authorities of the Requesting State. Such foreign authorities, having legitimate standing to participate in the cooperation process, may be represented by central authorities or by any other administrative or judicial authority of the Requested State, so long as it does not coincide with the authority competent to review compliance with public policy.

It should be stressed, however, that the role of intermediary authorities, such as the Central Authority should be limited to facilitating cooperation, so that they should be dispensed with whenever they are not necessary. The Requested State should encourage direct communication between the authorized parties and the authorities empowered to review international cooperation in the Requested State.

\section{Translation and interpretation in the process of international legal cooperation}

Understanding of the relevant languages is of fundamental importance to enable cooperation among States. It is therefore perfectly natural to recognize that States have the duty of assuming the costs of interpreters and translators for those who lack the necessary resources required for the process of international legal cooperation. Nevertheless, it is understanding rather than translation and interpreting that should be considered to be a sine qua non for 
international cooperation. Translation and interpretation may therefore be dispensed with in cases in which the requested authorities and interested parties are proficient in the language of the Requesting State.

\section{CONTENT OF THE DECISION RESULTING FROM THE REVIEW OF COMPATIBILITY WITH THE REQUESTED STATE'S PUBLIC POLICY}

How intensive must be the Requested State's review as to whether the requested act of cooperation on its territory is compatible with public policy? Should the review be limited to the public policy of the Requested State or be extended to the current laws of the Requesting State?

It is typical of legal systems resistant to international cooperation to extend their review process to include issues decided in the Requesting State without any connection with current public policy in the Requested State. This is so, because if the body of review in the Requested State becomes an instance of full appeal of the foreign decision, that State, in practice, will be setting itself up as a State with universal jurisdiction.

Thus, it is more consistent with a legal system open to international legal cooperation if the Requested State merely reviews it own public policy rather than examining the laws in effect in the Requesting State; as they say in Italian law, the Requested State should limit itself to a giudizio di delibazione.

An apparent exception to the above rule occurs with certain urgent measures in international legal cooperation. In principle, solely the court of the main trial is competent to order injunctive relief measures. Nevertheless, there are situations in which the urgency is so pressing that it would not be effective to apply for the urgent measure in one State so that it may be subsequently enforced in the territory of another State. The application for the injunctive relief may therefore be submitted directly to a court of the Requested State, in connection with a pending or future proceeding in the Requesting State. In that specific case, the court of the Requested State will not only review the public policy of its own country but will also be the responsible for examining issues of fumus boni iuris [likelihood of success on the merits of the case] and periculum in mora [danger in delay] of the judicial claim according to the laws in effect in the Requesting State. 


\section{EFFICACY OF THE PUBLIC POLICY REVIEW DECISION}

Is the public policy review decision a decision that nationalizes the act of cooperation within the Requested State and makes it equivalent to the other administrative and judicial decisions made there? In other words, can a proceeding before a foreign court or foreign administrative authority, if not contrary to the Requested State's public policy, give rise to the defense of litis pendens or res judicata in relation to other proceedings in progress in the Requested State?

In reality, denying such effects would amount to refusing cooperation: international legal cooperation would be useless if a future administrative or judicial decision by the authorities of the Requested State always took precedence over foreign decisions that have already been expressly or implicitly admitted by the review authorities of that same Requested State.

\section{TIMING OF THE PUBLIC POLICY REVIEW PROCESS}

What is the most appropriate time for the public policy review by the Requested State, before or after the requested act of cooperation has entered into effect?

The answer depends on the level of mutual trust between the States and thus the propensity of the Requested State's legal system to be more or less willing to cooperate with the Requesting State. A legal system that is not highly disposed to cooperate opts for a preliminary review, as under the laws of Brazil and the United Kingdom, which makes the enforcement of the foreign decision conditional on prior "recognition". Among the EU States, however, the United Kingdom opts for a more open system of cooperation, by allowing automatic recognition of judicial decisions and the possibility of retrospective reviews. 


\section{REFERENCE LIST}

Brazil, Civil Procedural Code of March 16, 2015.

Brazil, Law No. 13,445of May 24, 2017 (Law on Migration) (2017-June 2019).

EU, Council Framework Decision of June 13, 2002 on the European arrest warrant and the surrender procedures between Member States.

Mercosur, Agreement of December 10, 1998 on Extradition among Mercosur States.

Mercosur, Agreement of February 18, 2002 on Mutual Legal Assistance in Criminal Matters among Mercosur States, The Republic of Bolivia and the Republic of Chile.

Mercosur, Protocol of November 16, 1994, on Injunctive Relief Measures (Protocol of Ouro Preto).

Mercosur, Protocol of June 27, 1992 on judicial cooperation and Assistance in Civil, Commercial, Employment and Administrative Matters (Protocol of Las Leñas).

OAS (Organization of American States), Additional Protocol to the Inter-American Convention on Letters Rogatory (B-46).

OAS, Inter-American Convention on Execution of Preventive Measures (B-42).

OAS, Inter-American Convention on Extraterritorial Validity of Foreign Judgments and Arbitral Awards (B-41).

OAS, Inter-American Convention on International Commercial Arbitration (B-35).

OAS, Inter-American Convention on Letters Rogatory (B-36).

Regulation (EU) 2015/848 of the European Parliament and of the Council of 20 May 2015 on insolvency proceedings, OJ L 141.

Regulation (EU) n. 1215/2012 of the European Parliament and of the Council of 12 December 2012 on jurisdiction and the recognition and enforcement of judgments in civil and commercial matters.

The Hague Conference on Private International Law, Convention of 24 October 1956 on the law applicable to maintenance obligations towards children.

The Hague Conference on Private International Law, Convention of 15 April 1958 concerning the recognition and enforcement of decisions relating to maintenance obligations towards children.

The Hague Conference on Private International Law, Convention of 2 July 2019 on the Recognition and Enforcement of Foreign Judgments in Civil or Commercial Matters.

The Hague Conference on Private International Law, The Convention of 25 October 1980 on the Civil Aspects of International Child Abduction.

The Pan-American Union, Code of Private International Law ("Bustamante Code"), annexed to the convention signed at Havana, February 20, 1928.

United Kingdom of Great Britain and Northern Ireland, Crime International Cooperation Act, 2003, http://www.legislation.gov.uk/ukpg a/2003/32/pdfs/ukpga_20030032_en.pdf. 
United Kingdom of Great Britain and Northern Ireland, Obtaining Assistance from the UK in Asset Recovery, https://star.worldbank.org/ document/uk-guide-asset-recovery.

United Kingdom of Great Britain and Northern Ireland, Requests for Mutual Legal Assistance in Criminal Matters - Guidelines for Authorities Outside of the United Kingdom - 2015, https://www.gov.uk/government/uploads/system/ uploads/attachment_data/ file/415038/ MLA_Guidelines_2015.pdf.

United Kingdom of Great Britain and Northern Ireland, Treaty between the Government of the United Kingdom of Great Britain and Northern Ireland and the Government of the Federative Republic of Brazil on Mutual Legal Assistance in Criminal Matters, London, April 7, 2005.

United Nations, Convention on the Recognition and Enforcement of Foreign Arbitral Awards (New York, 1958). 